Article

\title{
Concentration of Immunoglobulins in Microfiltration Permeates of Skim Milk: Impact of Transmembrane Pressure and Temperature on the IgG Transmission Using Different Ceramic Membrane Types and Pore Sizes
}

\author{
Hans-Jürgen Heidebrecht ${ }^{1, *}$, José Toro-Sierra ${ }^{1,2}$ and Ulrich Kulozik ${ }^{1,3}$ \\ 1 Chair for Food and Bioprocess Engineering, Technical University of Munich, Weihenstephaner Berg 1, \\ 85354 Freising, Germany; toro.jose@live.com (J.T.-S.); ulrich.kulozik@tum.de (U.K.) \\ 2 Kraft Foods R\&D Inc./Mondelēz International GmbH, 82008 Unterhaching, Germany \\ 3 ZIEL Institute for Food \& Health, Technical University of Munich, Weihenstephaner Berg 1, \\ 85354 Freising, Germany \\ * Correspondence: Heidebrecht@tum.de; Tel.: +49-8161-71-3481
}

Received: 30 May 2018; Accepted: 26 June 2018; Published: 28 June 2018

\begin{abstract}
The use of bioactive bovine milk immunoglobulins (Ig) has been found to be an alternative treatment for certain human gastrointestinal diseases. Some methodologies have been developed with bovine colostrum. These are considered in laboratory scale and are bound to high cost and limited availability of the raw material. The main challenge remains in obtaining high amounts of active IgG from an available source as mature cow milk by the means of industrial processes. Microfiltration (MF) was chosen as a process variant, which enables a gentle and effective concentration of the Ig fractions (ca. $0.06 \%$ in raw milk) while reducing casein and lactose at the same time. Different microfiltration membranes (ceramic standard and gradient), pore sizes $(0.14-0.8 \mu \mathrm{m})$, transmembrane pressures $(0.5-2.5 \mathrm{bar})$, and temperatures $\left(10,50^{\circ} \mathrm{C}\right)$ were investigated. The transmission of immunoglobulin $\mathrm{G}(\mathrm{IgG})$ and casein during the filtration of raw skim milk ( $<0.1 \%$ fat $)$ was evaluated during batch filtration using a single channel pilot plant. The transmission levels of IgG $(\sim 160 \mathrm{kDa})$ were measured to be at the same level as the reference major whey protein $\beta-\operatorname{Lg}(\sim 18 \mathrm{kDa})$ at all evaluated pore sizes and process parameters despite the large difference in molecular mass of both fractions. Ceramic gradient membranes with a pore sizes of $0.14 \mu \mathrm{m}$ showed IgG-transmission rates between $45 \%$ to $65 \%$ while reducing the casein fraction below $1 \%$ in the permeates. Contrary to the expectations, a lower pore size of $0.14 \mu \mathrm{m}$ yielded fluxes up to $35 \%$ higher than $0.2 \mu \mathrm{m} \mathrm{MF}$ membranes. It was found that low transmembrane pressures benefit the Ig transmission. Upscaling the presented results to a continuous MF membrane process offers new possibilities for the production of immunoglobulin enriched supplements with well-known processing equipment for large scale milk protein fractionation.
\end{abstract}

Keywords: immunoglobulin G; microfiltration; milk protein fractionation; ceramic membranes

\section{Introduction}

The natural function of the major bovine immunoglobulin $\mathrm{G}(\mathrm{IgG})$ class is to agglutinate pathogens and enhance the complement system. It, therefore, protects the calf from pathogens [1]. This function renders immunoglobulins (Ig) an interesting material for various food supplements and pharmaceutical applications. Such products are used to support the immune system, respectively, which may be used to treat gastrointestinal human diseases after immunizing the cow with the relevant antigen $[1,2]$. Typically, these products are obtained from colostrum and milk, which is secreted by the cow directly 
a few hours after parturition. Colostrum naturally contains very high immunoglobulin concentrations (2-20\%) [3]. However, the downside of using colostrum is that it is only available a few hours after the birth of a calf and it is needed for its breeding, which makes it difficult to collect large quantities. Contrary to colostrum, mature milk is abundant but lower in the immunoglobulin content. For this reason, some researchers used mature cow milk as a starting material to obtain a rennet whey concentrate containing specific Ig for the treatment of Clostridium difficile induced diarrhea [4-6].

However, due to the low concentration of $0.06 \%$ to $0.08 \%(w / w)$ of Ig in raw milk, it is necessary to enrich the immunoglobulin fraction to achieve a high enough concentration for certain biological functionalities in humans. In order to do so, one of the first steps is casein removal. While acid casein precipitation might lead to the degradation of the immunoglobulins [7], precipitation by chymosin requires a downstream heating step to inactivate chymosin, which affects the stability of the immunoglobulins [8]. In parallel, rennet whey contains caseinomacropeptide derived from the cleavage of kappa-casein by chymosin, which results in a lower purity of Ig in relation to the total protein content. In contrast, microfiltration (MF) is a comparatively gentle process. The use of nominal pore sizes in the range of $0.1-0.2 \mu \mathrm{m}$ not only enables the removal of casein micelles but also the remaining fat globules $(0.2-6 \mu \mathrm{m})$, microorganisms $(0.2-15 \mu \mathrm{m})$, and somatic cells $(6-15 \mu \mathrm{m})$. The resulting casein free milk serum, in manufacturing environments referred to as 'ideal whey' or 'native whey', has the native milk pH and is free from caseinomacropeptide and cheese curd particles. Therefore, it is clear in appearance and, most importantly, virtually free from microorganisms $[9,10]$. The focus of recent research regarding milk protein fractionation by microfiltration concentrated on the separation of casein micelles and the major whey proteins $\alpha$-lactalbumin $(\alpha-\mathrm{La})$ and $\beta$-lactoglobulin $(\beta-\mathrm{Lg})$ and /or the quantification of the obtained casein/whey protein ratio in the MF concentrate [11-21]. However, there is a lack of information regarding the performance of the membranes for separating minor whey proteins such as the immunoglobulin fraction. The decisive question originates from the fact that the major immunoglobulin class IgG (146-163 kDa) [3] is approximately 10 times larger in molecular mass when compared to the major whey proteins (14-18 kDa). As far as reported for $\alpha$-La and $\beta$-Lg, a transmission of ca $50 \%$ of the available protein in skim milk into the MF permeate can be expected [15]. Two studies showed that it is possible to separate casein and IgG with microfiltration (at a pore size of $0.1 \mu \mathrm{m}$ ) from colostrum, but they reported low recovery rates of $64 \%$ [22], respectively. This includes a maximum transmission of $25 \%$ for IgG through the membrane [10]. The same group also reported transmission levels above $99 \%$ for IgG during the concentration of skim milk with microfiltration [10], which is diametrically different and in disagreement with $30 \%$ transmission observed by Le Berre and Daufin (1998) during the filtration of heat-treated and mineral modified milk [23].

The aim of this work was to determine whether it is possible to use microfiltration for the fractionation of casein micelles and IgG at high transmission levels. This paper aims to compare, in a quantitative form, the transport of IgG through the MF membrane with the much smaller major whey proteins $\alpha$-La and $\beta$-Lg. In this context, the impact of transmembrane pressure and temperature on the IgG transmission was studied using different membrane types and pore sizes. It was found that ceramic gradient membranes with a pore size of $0.14 \mu \mathrm{m}$ featured IgG-transmission rates between $45 \%$ to $65 \%$ while reducing the casein fraction below $1 \%$ in the permeates. This is comparable to the transmission of $\alpha$-La and $\beta$-Lg despite the large (up to $10 \times$ ) differences in molecular mass. The presented results show that upscaling the process to a continuous MF membrane process might offer new possibilities for the production of immunoglobulin-enriched supplements.

\section{Materials and Methods}

\subsection{Microfiltration of Skim Milk}

Raw skim milk was obtained from local dairy or raw milk directly from a local experimental farm to avoid thermally-induced interactions between casein micelles and immunoglobulins as well as thermal degradation of the immunoglobulins due to pasteurization. The raw milk was separated 
with a pilot cream separator type MM 1254 D (GEA Westfalia Group GmbH, Oelde, Germany) at $8.000 \mathrm{~g}$ and $50{ }^{\circ} \mathrm{C}$ to obtain a fat content below $0.1 \%$ in the skim milk. The skim milk was either cooled to $4{ }^{\circ} \mathrm{C}$ with a plate heat exchanger and processed the following day or was subjected directly to the same microfiltration unit as described by Kühnl et al. [17]. The microfiltration was operated in a crossflow mode with a closed loop using ceramic ISOFLUX ${ }^{\circledR}$ and standard (TAMI Industries, Nyons, France) membranes (support and selective layer titanium dioxide) both with nominal cutoffs of $0.14 \mu \mathrm{m}, 0.2 \mu \mathrm{m}, 0.45 \mu \mathrm{m}$, or $0.8 \mu \mathrm{m}$. The membrane featured an area of $0.35 \mathrm{~m}^{2}, 1178 \mathrm{~mm}$ length, $25 \mathrm{~mm}$ diameter, 23 channels, and $3.5 \mathrm{~mm}$ equivalent hydraulic diameter per channel.

\subsection{Operating Conditions during Microfiltration}

Prior to filtration, the membrane was cleaned and conditioned with $0.5 \%$ Ultrasil 14 caustic solution (Ecolab, Düsseldorf, Germany) at $60^{\circ} \mathrm{C}$ for $20 \mathrm{~min}$. The preheated membrane was extensively flushed with softened water and cooled down to a filtration temperature of $50{ }^{\circ} \mathrm{C} \pm 1{ }^{\circ} \mathrm{C}$ or $10{ }^{\circ} \mathrm{C} \pm 1{ }^{\circ} \mathrm{C}$ The filtrations were performed in batch mode for 90 min with $30 \mathrm{~L}$ of skim milk of which the first $5 \mathrm{~L}$ of retentate were discarded to avoid a dilution by rinsing water. Sampling of retentate and permeate from the feed tank was performed, respectively. The permeate pipeline was performed after $0 \mathrm{~min}, 10 \mathrm{~min}, 20 \mathrm{~min}, 30 \mathrm{~min}, 45 \mathrm{~min}, 60 \mathrm{~min}$, and $90 \mathrm{~min}$. Samples were analyzed for $\beta-\mathrm{Lg}, \alpha$-La, BSA and IgG, and casein, as described in Section 2.3. At the same time points, the permeate flux $(\mathrm{J})$ was measured gravimetrically and converted to liters by dividing the values by the density at the equivalent temperature. The MF-process was operated at a transmembrane pressure $\Delta \mathrm{p}_{\mathrm{TM}}=1$ bar. If not stated otherwise, wall shear stress $\tau_{\mathrm{w}}=150 \mathrm{~Pa} \pm 5 \mathrm{~Pa}$ (equivalent to 2 bar pressure drop). The $\Delta \mathrm{p}_{\text {тм }}$ was calculated according to Equation (1) with $\mathrm{p}_{\text {inlet }}$ and $\mathrm{p}_{\text {outlet }}$ as the pressures at the membrane inlet and outlet, respectively. The pressure on the permeate side permeate was adjusted with a manual valve to achieve low $\Delta \mathrm{p}_{\mathrm{TM}}$.

$$
\mathrm{P}=\frac{\mathrm{p}_{\text {inlet }}+\mathrm{p}_{\text {outlet }}}{2}-\mathrm{p}_{\text {permeate }}
$$

The transmission (P) was calculated, according to Equation (2), as the ratio of the concentration of the equivalent component in the permeate $\left(\mathrm{C}_{\text {per }}\right)$ and retentate $\left(\mathrm{C}_{\text {ret }}\right)$.

$$
\mathrm{P}=\frac{\mathrm{C}_{\mathrm{perm}}}{\mathrm{C}_{\mathrm{ret}}} \cdot 100 \%
$$

After an experiment, the plant was flushed with water and cleaned in a three-step procedure (alkaline-acid-alkaline), which was described by Kühnl et al. [17]. The cleaning efficacy was validated by measuring the water flux at fixed conditions.

\subsection{Measurement of Immunoglobulin $G$ with Reversed-Phase High-Performance Liquid Chromatography}

The quantitative determination of native IgG, $\beta$-Lg, $\alpha$-La, and blood serum albumin (BSA) in one run was conducted by reversed-phase high-performance liquid chromatography (RP-HPLC) with an elution profile of acetonitrile and water in the mobile phase, according to Kessler and Beyer (1991) [24] with the gradient and column modifications described by Toro-Sierra et al. (2013) [25]. Calibration was carried out using purified bovine IgG, $\beta$-Lg, $\alpha$-La, and blood serum albumin (BSA) (Sigma, Steinheim, Germany). Before analysis, the $\mathrm{pH}$ of all samples was adjusted to 4.6 with $1 \mathrm{M} \mathrm{HCl}$ in order to precipitate casein micelles and denatured whey proteins. The supernatant of all samples was filtered through $0.45 \mu \mathrm{m}$ syringe filters and injected into the RP-HPLC. 


\subsection{Measurement of Casein with RP-HPLC}

The quantitative determination of the single casein fractions $\alpha \mathrm{S} 1, \alpha \mathrm{S} 2, \beta$, und $\kappa$-Casein was done with RP-HPLC, according to Bonfattti et al. [26] using the buffer according to Bonizzi et al. (2009) [27]. Shortly, $400 \mu \mathrm{l}$ of sample were mixed with $1600 \mu \mathrm{L}$ buffer (Tris(hydroxymethyl)aminomethane (TRIS, $\left.0.165 \mathrm{~mol} \mathrm{~L}^{-1}\right)$, urea $\left(8.000 \mathrm{~mol} \mathrm{~L}^{-1}\right)$, sodium-citrate $\left(0.044 \mathrm{~mol} \mathrm{~L}^{-1}\right)$, and $\beta$-mercaptoethanol $(0.3 \%$ $\mathrm{v} / \mathrm{w})$. The solution was filtered $(0.45 \mu \mathrm{m})$ and injected into vials. The separation was carried out with an Agilent Zorbax 300SB-C18 $150 \times 4.6 \mathrm{~mm}$ resin (Agilent Technologies, Böblingen, Germany) and the gradient elution (Eluent $\mathrm{A}, 10 \%$ acetonitrile $\left(1 \mathrm{~mL} \mathrm{~L}^{-1}\right.$ trifluoroacetic acid). Eluent $\mathrm{B}, 90 \%$ acetonitrile $\left(0.7 \mathrm{~mL} \mathrm{~L}^{-1}\right.$ trifluoroacetic) was carried out at $1.2 \mathrm{~mL} \mathrm{~min}^{-1}$.

\section{Results and Discussion}

\subsection{IgG Transmission as a Function of Time and Pore Size}

The aim of the microfiltration when used for casein fractionation is to completely retain the casein micelles with a spread in diameter between 50-400 $\mathrm{nm}\left(\mathrm{d}_{50,3}=180-200 \mathrm{~nm}\right)$ while maximizing the transmission of the whey proteins ranging from $14 \mathrm{kDa}$ for $\alpha$-La up to IgG (146-163 kDa) or more for other immunoglobulin fractions. In this way, the ratio of casein to whey proteins is modified from 80:20 (w/w) as present in raw bovine milk towards higher casein concentrations e.g., $90: 10$ or 95:5 in the retentate. In milk protein fractionation by microfiltration, the retained proteins form a deposit layer, which influences the filtration performance in terms of flux and protein transmission [11,16]. Therefore, an accurate prediction of the Ig transmission by comparing the nominal pore size of the MF membrane and the molecular size is not possible. Figure 1 shows the $\operatorname{IgG}(\mathrm{A})$ and $\beta-\operatorname{Lg}(\mathrm{B})$ as well as casein transmission as a function of time. The flux is presented in Figure $2 \mathrm{~A}, \mathrm{~B}$, which summarizes the data as a function of the different pore sizes at steady state conditions.
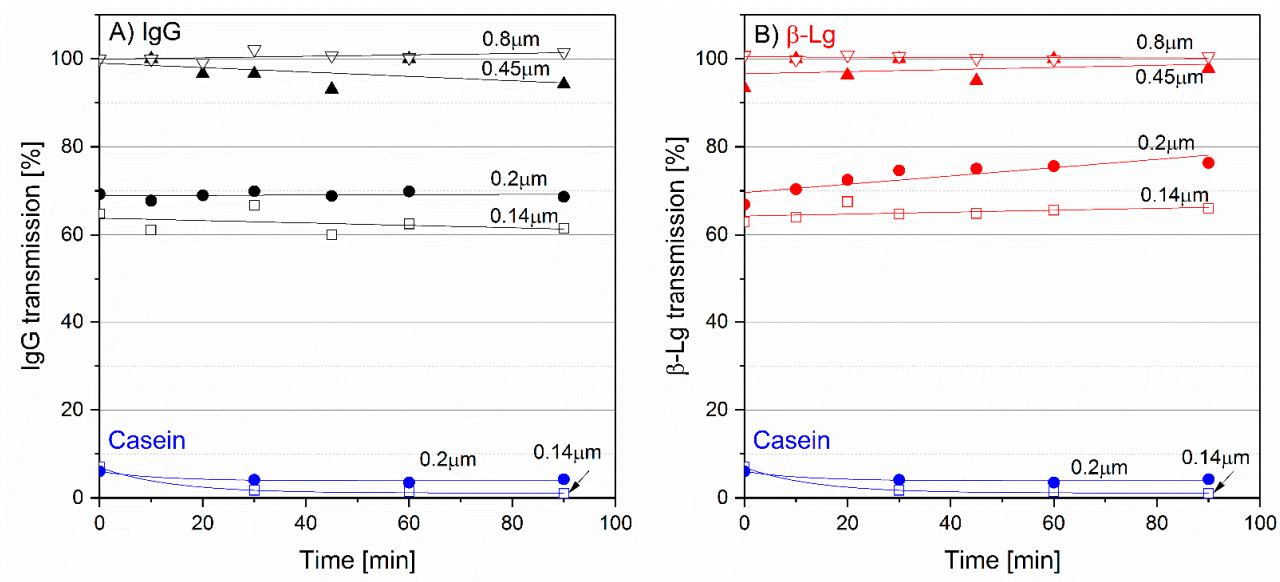

Figure 1. IgG (black) and casein(blue) (A) and $\beta$ - $\mathrm{Lg}$ (red) and casein (blue) (B) transmission as a function of time at a pore size of $0.14 \mu \mathrm{m}(\square)$ belonging illustrated by the arrow), $0.2 \mu \mathrm{m}(\bullet), 0.45 \mu \mathrm{m}$ $(\Delta), 0.8 \mu \mathrm{m}(\Delta)$ (gradient membrane, $50^{\circ} \mathrm{C}$ ). For casein transmission of $0.45 \mu \mathrm{m}$ and $0.8 \mu \mathrm{m}$ membranes, see the Supplementary Material. 

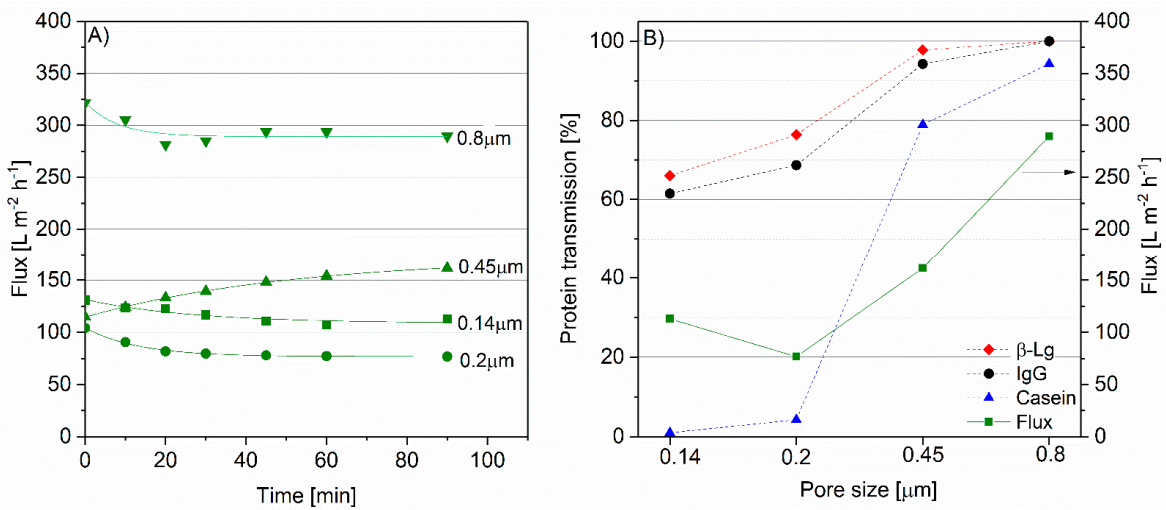

Figure 2. Flux (green) as a function of the time at different pore sizes (A), IgG, $\beta$ - $\mathrm{Lg}$, casein transmission plus flux as a function of pore size at steady state conditions after $90 \mathrm{~min}$ of filtration (B) (gradient membrane, $50{ }^{\circ} \mathrm{C}$ ). Arrow indicates the belonging of the flux curve to the right y-axis.

The transmission levels of IgG (Figure 1A) were found to be at the same level as the reference major whey protein $\beta-\mathrm{Lg}(18 \mathrm{kDa})$ (Figure 1B) at all evaluated pore sizes despite the large difference in the molecular size of both fractions. A reason for the comparatively good transmission behavior of IgG might be its flexibility and shape. IgG consists of two heavy chains and two light chains, which are connected via disulphide bonds (Scheme 1). The constant region $(\mathrm{CH} 1)$ and variable region $(\mathrm{VH})$ of the heavy chain form together with the constant (CL) and variable region (VL) of the light chain in the fragment antigen-binding (Fab). The constant regions $\mathrm{CH} 2$ and $\mathrm{CH} 3$ of the two heavy chains form the fragment crystallizable $(\mathrm{Fc})[3,28,29]$. The Fab and $\mathrm{Fc}$ region are connected by a hinge region with no secondary structure (Scheme 1A). From a functional perspective, this gives the molecule a high flexibility so that the two Fab regions can interact with different epitopes of antigens. From a filtration perspective, this flexibility might contribute to the fact that the proteins can pass the deposit layer and membrane-like globular proteins, which is 10 times lower in molecular sizes such as $\beta$-Lg.
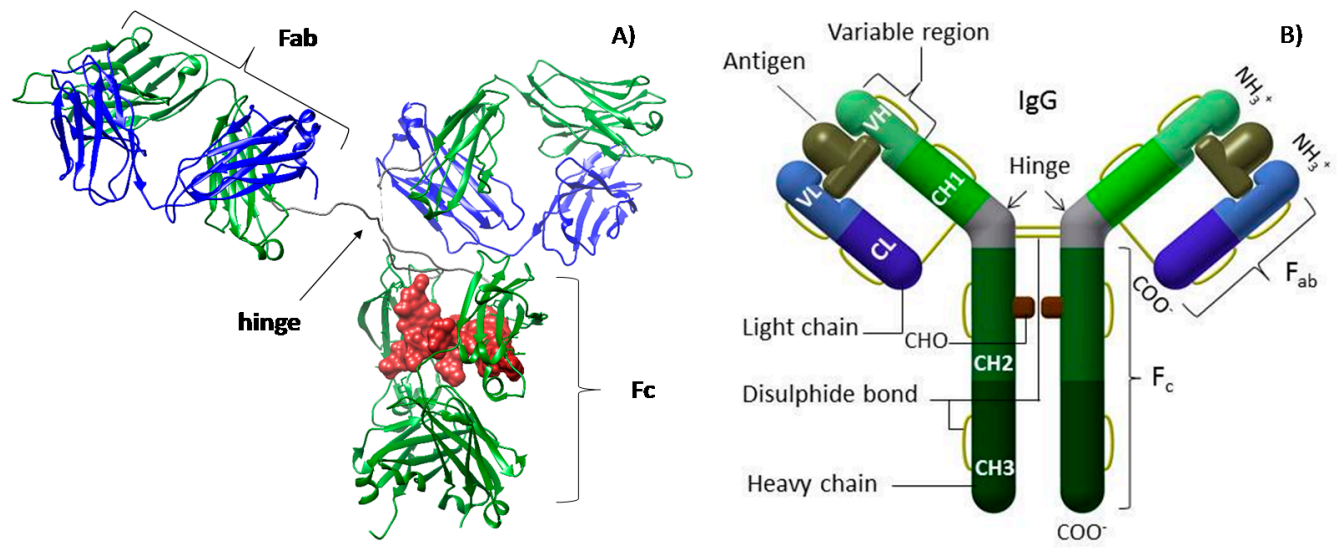

Scheme 1. Three dimensional (A) and schematic (B) structure of IgG. Heavy chains (green), light chains (blue), disulphide bonds (yellow), constant (CH1), and variable region (VH) of the heavy chain, the constant (CL) and variable region (VL) of the light chain, fragment antigen binding (Fab), and the fragment crystallizable ( $\mathrm{Fc})$. Three-dimensional structure generated with UCSF Chimera [30] using pdb code 1HZH from the RCSB Protein Data Bank [31]. Schematic structure drawn with AutoCAD and modified from References [28,29].

There was an initial flux decline for membranes with nominal pore sizes of $0.14 \mu \mathrm{m}, 0.2 \mu \mathrm{m}$, and $0.8 \mu \mathrm{m}$ (Figure 2A), which can be attributed to initial fouling during the transition from water to milk [32]. After approximately $30 \mathrm{~min}$, the steady state was reached. Strikingly, the flux increased by 
ca. $30 \%$ when changing to the membrane with the pore size of $0.2 \mu \mathrm{m}$ to $0.14 \mu \mathrm{m}$. This lower flux of the $0.2 \mu \mathrm{m}$ membrane might be attributed to pore blocking. The casein micelles feature a particle size distribution range of $50-400 \mathrm{~nm}$ with a mean of $180-200 \mathrm{~nm}$. This means the average particle size of the casein micelles matches the nominal pore size of the $0.2 \mu \mathrm{m}$ membrane, which might lead to the blocking of the membrane pores rather than forming a deposit layer on top of the membrane, which can be assumed for the $0.14 \mu \mathrm{m}$ membrane [33]. Initial pore blocking might also be responsible for the initial low flux for the $0.45 \mu \mathrm{m}$ membrane, which increased by $30 \%$ along the filtration time.

The ceramic gradient membranes with pore sizes of $0.14 \mu \mathrm{m}$ and $0.2 \mu \mathrm{m}$ showed IgG-transmission rates over $60 \%$ while reducing the casein fraction below $1 \%(0.14 \mu \mathrm{m})$ and $4 \%(0.2 \mu \mathrm{m})$ in the permeates, respectively (Figure 2B). For the casein fraction, similar amounts of $1.4 \%$ were reported using a pore size of $0.2 \mu \mathrm{m}$ in the uniform transmembrane pressure mode (UTP) while, at a pore size of $0.1 \mu \mathrm{m}$, the casein transmission was negligible [21]. Even though $4 \%$ does not seem to be much, due to the different ratio of casein micelles of $(80 \%)$ to whey proteins $(20 \%)$ in skim milk, already minor protein transmission led to relatively large impurities in the MF-permeate. Even though typical pore sizes of ceramic membranes for casein whey protein fractionation are between 0.05 and $0.2 \mu \mathrm{m}$ [34], larger pore sizes were tested because the IgG transmission was expected to be at a lower level at the smaller pore sizes. However, even though the IgG transmission was above $90 \%$ for the pore sizes of $0.45 \mu \mathrm{m}$ and $0.8 \mu \mathrm{m}$, the high casein transmission of $>75 \%$ renders these membranes unsuitable for this fractionation task.

\subsection{Impact of Membrane Type on IgG Transmission and Flux}

The used gradient membranes (Figures 1 and 2) possess a thickness gradient of the selective layer along the membrane, which creates a longitudinal decreasing the membrane resistance (Scheme 2). This means that the higher $\Delta \mathrm{p}_{\mathrm{TM}}$ at the membrane inlet compared to the outlet is compensated by a higher membrane resistance at the inlet and a lower resistance at the outlet, which means the permeate volumetric flow is constant along the entire membrane element. By decreasing the membrane resistance corresponding to the decreasing $\Delta \mathrm{p}_{\mathrm{TM}}$ along the membrane, the same flux (isoflux) is generated with the objective to improve the overall filtration performance. However, the standard membrane (Scheme 3) does not have a resistance gradient. Therefore, there is a flux decline along the membrane. Moreover, the higher $\Delta \mathrm{p}_{\mathrm{TM}}$ at the inlet provokes a more intense deposit layer formation at the inlet, which effects both the flux and protein transmission [16]. However, the retentate pressure drop along the membrane depends on the material, the length of the membrane, the hydrodynamic diameter, the density of the fluid, and the fluid viscosity. As for a given temperature, the density and the membrane characteristic are constant. The pressure drop is directly proportional to the flow velocity. Therefore, the fixed membrane resistance gradient requires a defined pressure drop or crossflow velocity, respectively. Therefore, it renders the operation of the filtration plant inflexible.

Figure 3 shows the protein transmission and flux as a function of the pore size at steady state conditions using standard membranes. The transmission of IgG was $28 \%$ for the $0.14 \mu \mathrm{m}$ pore size compared to $60 \%$ by using the equivalent gradient membrane at the same process conditions. The reason for the inferior performance could be an inhomogeneous deposit (as indicated in Scheme 3). Even though the initial overall permeate fluxes with both membranes were comparable $\left(138 \mathrm{~L} \mathrm{~m}^{-2} \mathrm{~h}^{-1}\right.$ versus $131 \mathrm{~L} \mathrm{~m}^{-2} \mathrm{~h}^{-1}$, see Supplementary Material Figure S2), during the transition from water to milk, the flux at the membrane inlet should be higher for the standard membrane due to the missing additional membrane resistance $\mathrm{R}_{\mathrm{m}}$. Therefore, the convective transport of particles to the membrane surface is higher, which in turn leads to a more intense deposit layer formation especially at the inlet of the membrane. This negatively effects the overall protein transmission. The flux was similar for both membranes. For the other pore sizes, the casein transmission was too high in order to allow the fractionation of $\operatorname{IgG}$ and casein. In conclusion, the separation of $\operatorname{IgG}$ and casein with a pore size of $0.14 \mu \mathrm{m}$ using a conventional membrane is feasible. Nevertheless, due to their better performance, the gradient membranes were used for further experiments. 


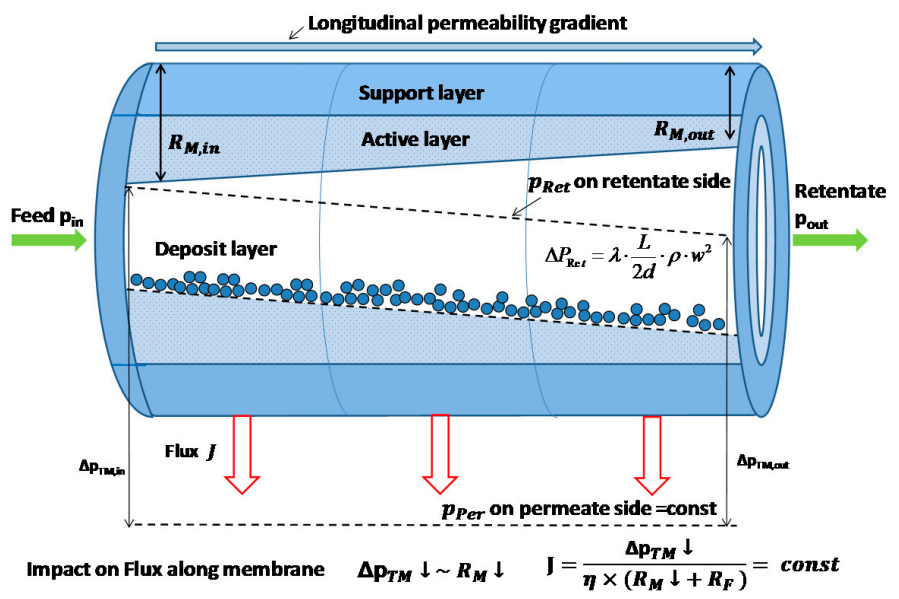

Scheme 2. Schematic description of the used gradient membrane. Concept of TAMI Industries, modified from [35]. Flux J, transmembrane pressure $\Delta \mathrm{p}_{\mathrm{TM}}$, dynamic viscosity $\eta$, membrane resistance $R_{M}$, and fouling resistance $R_{F}$. The indices in and out refer to the membrane inlet and membrane outlet.

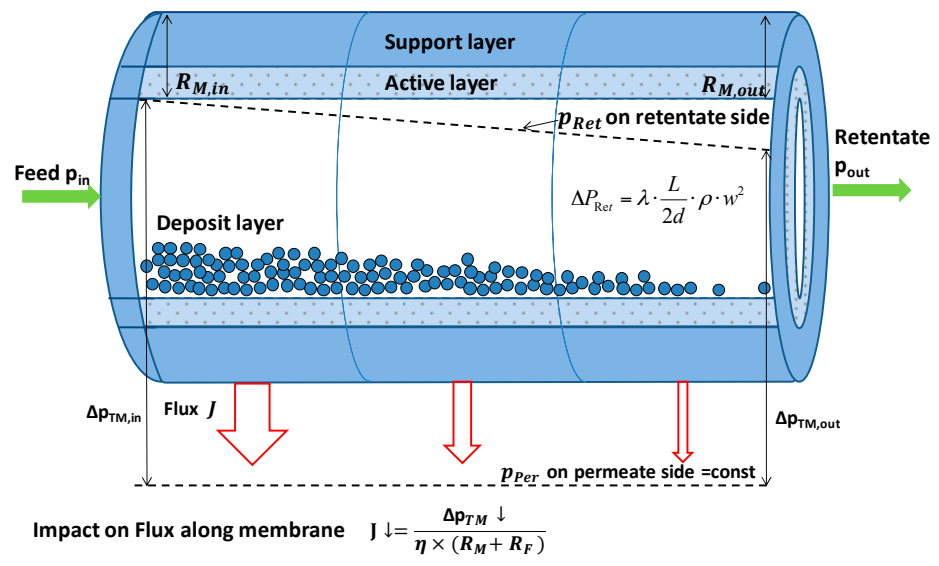

Scheme 3. Schematic description of a standard membrane. Flux J, transmembrane pressure $\Delta \mathrm{p}_{\mathrm{TM}}$, dynamic viscosity $\eta$, membrane resistance $R_{M}$, and fouling resistance $R_{F}$. The indices in and out refer to the membrane inlet and membrane outlet.

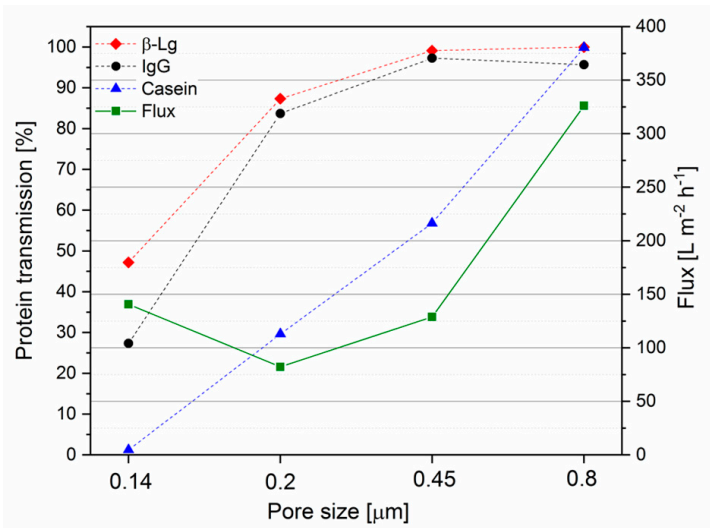

Figure 3. IgG and casein transmission as well as flux function at different pore sizes using ceramic standard membranes at a steady state flux after $90 \mathrm{~min}$ of filtration at $50{ }^{\circ} \mathrm{C}$. For time dependent data, see Supplementary Data. 


\subsection{Impact of Transmembrane Pressure on IgG Transmissionand Flux at Different Pore Sizes}

It is well known that the transmembrane pressure has a major impact on the filtration performance [36]. Figure 4 shows the flux and the protein transmission as a function of the nominal pore size. The flux difference between $\Delta \mathrm{p}_{\mathrm{TM}}=1$ bar and $\Delta \mathrm{p}_{\mathrm{TM}}=2$ bar was below $10 \%$ for the pore sizes $0.14 \mu \mathrm{m}, 0.2 \mu \mathrm{m}$, and $0.45 \mu \mathrm{m}$, which indicates that the limiting flux was already reached at 1 bar of the transmembrane pressure. Even though the applied transmembrane pressure did not have a great impact on the flux, the IgG transmission decreased to 50\% when increasing the pressure from $\Delta \mathrm{p}_{\mathrm{TM}}=1$ bar to $\Delta \mathrm{p}_{\mathrm{TM}}=2$ bar, which is in agreement with previously reported data for the major whey proteins $[16,37,38]$. The decrease can be attributed to the higher compactness of the deposit layer and, therefore, a reduction of the porosity of the fouling layer takes place, which in turn results in a reduction of protein transmission.
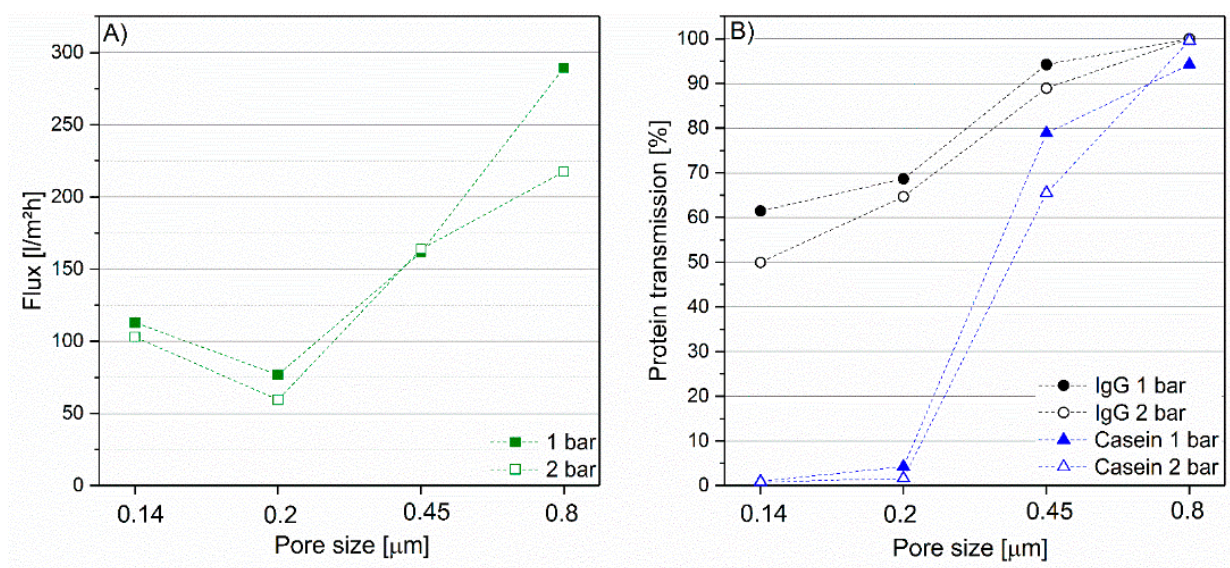

Figure 4. Flux (A) and IgG plus casein transmission (B) as a function of pore size at 1 bar (filled symbols) and 2 bar (open symbols) (gradient membrane, $50{ }^{\circ} \mathrm{C}$ ). For equivalent of $\beta$ - $\mathrm{Lg}$ and time dependent data, see Supplementary Information.

The impact of the transmembrane pressure on IgG and $\beta$ - Lg transmission was studied in more detail for the chosen pore size of $0.14 \mu \mathrm{m}$ (Figure 5). For a better comparison, the protein transmission of the second largest whey protein fraction $\alpha$-La as well as blood serum albumin (BSA) as a reference for a larger whey protein was studied. The transmission of BSA was around $10 \%$ to $25 \%$ depending on the applied pressure, which is in the range of previously reported data [36]. Even though the molecular mass (66.4 kDa) [39] and mean hydrodynamic diameter $(6.4 \mathrm{~nm})$ [23] of BSA are lower than IgG with $(146-163 \mathrm{kDa})$ [3] and $10.4 \mathrm{~nm}$ [23], the transmission of IgG (45-55\%) was significantly higher than that of BSA (10-20\%). This substantiates the hypothesis formulated in chapter 3.1 that the size must be responsible for comparatively good transmission of IgG, which should be studied in more detail. For the other whey proteins, the transmission was similar and approximately constant with $40 \%$ for $\beta$ - $\mathrm{Lg}$ and $45-50 \%$ for $\alpha$-La at different transmembrane pressure levels (1.5 bar, 2.0 bar, and 2.5 bar). For the lower applied transmembrane pressure of 1.0 bar and 0.6 bar, the transmission was higher. This again can be attributed to the deposit layer, which is less intense and compact at the lower pressure due to the lower convective transport of particles to the membrane. 


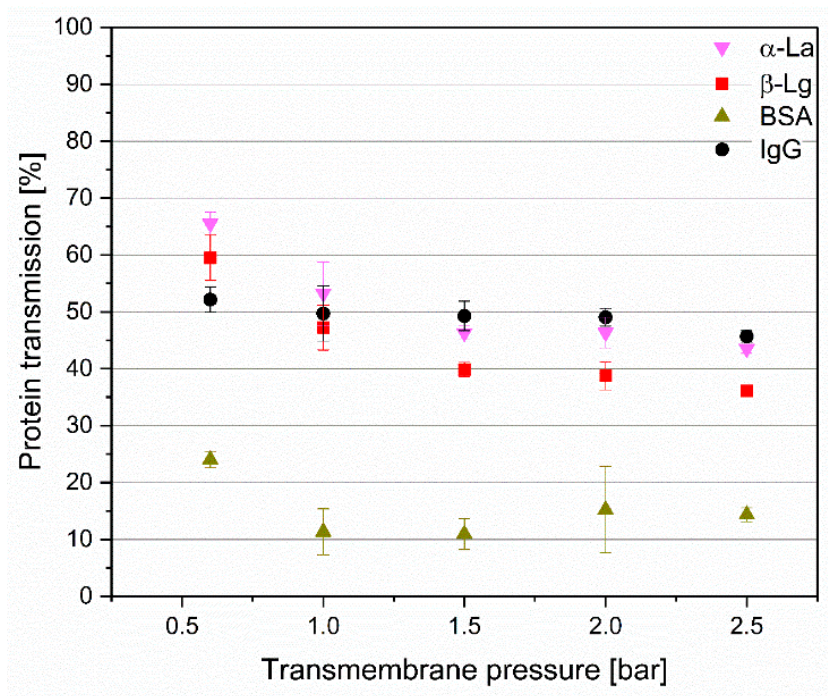

Figure 5. Protein transmission of IgG, $\alpha-\mathrm{La}, \beta-\mathrm{Lg}$, and blood serum albumin (BSA) as a function of the transmembrane pressure at a pore size of $0.14 \mu \mathrm{m}$ (gradient membrane, $50{ }^{\circ} \mathrm{C}$ ). Error bars represent standard error of triplets.

\subsection{Impact of Temperature on IgG Transmission and Flux}

For microbiological reasons, milk protein fractionation with microfiltration is carried out at either cold temperatures around $10{ }^{\circ} \mathrm{C}[37,40]$, i.e., below the growth optimum of microorganism in milk or at $50-55{ }^{\circ} \mathrm{C}[12,37,41]$, i.e., above the microbiological growth optimum. Especially for ceramic membranes, higher temperatures are preferred due to the lower viscosity of the retentate and the inherent advantages during long production runs. Figure 6 shows the transmission of $\operatorname{IgG}$ and casein at $10{ }^{\circ} \mathrm{C}$ and $50{ }^{\circ} \mathrm{C}$ at $\Delta \mathrm{p}_{\mathrm{TM}}=1$ bar (A), respectively. $\Delta \mathrm{p}_{\mathrm{TM}}=2$ bar (B) as a function of the pore size. The casein transmission was similar at both temperatures. However, it should be noted that, during extended filtration times whereupon the permeate is collected and concentrated with an ultrafiltration unit, there might be an accumulation of $\beta$-casein at $10^{\circ} \mathrm{C}$ in the whey [42,43]. The IgG transmission was $20 \%$ to $30 \%$ lower at $10{ }^{\circ} \mathrm{C}$ compared to $50{ }^{\circ} \mathrm{C}$ at the same operating conditions. A reason for the lower transmission could be due to the lower flow velocity in the laminar boundary layer of the membrane where fouling takes place. The thickness of this boundary can be estimated according to Equation (3) [44].

$$
\delta_{\text {lam }}=5 \cdot v \cdot \sqrt{\rho / \tau_{w}}
$$

At $10^{\circ} \mathrm{C}$, the kinematic viscosity of skim milk is about two times higher $\left(1.48 \times 10^{-6} \mathrm{~m}^{2} \mathrm{~s}^{-2}\right.$ versus $7.84 \times 10^{-7} \mathrm{~m}^{2} \mathrm{~s}^{-2}$ at $50^{\circ} \mathrm{C}$ ), which means the laminar boundary layer is approximately two times thicker $\left(1.02 \times 10^{-5} \mathrm{~m}\right.$ versus $\left.1.95 \times 10^{-5} \mathrm{~m}\right)$. This, in turn, leads to a less turbulent flow profile directly above the membrane, which again effects the deposit layer and protein transmission [45]. The flux was at $39 \mathrm{~L} \mathrm{~m}^{-1} \mathrm{~h}^{-1}\left(\Delta \mathrm{p}_{\mathrm{TM}}=1 \mathrm{bar}\right)$, respectively, and $44 \mathrm{~L} \mathrm{~m}^{-1} \mathrm{~h}^{-1}\left(\Delta \mathrm{p}_{\mathrm{TM}}=2 \mathrm{bar}\right)$ for the pore size of $0.14 \mu \mathrm{m}$. Therefore, $35 \%$ or $43 \%$, respectively, of the flux at $50{ }^{\circ} \mathrm{C}$ can be attributed to the higher viscosity and density at the lower temperature $[37,45]$. In addition, the same effect of the decreasing flux with increasing pore size from $0.14 \mu \mathrm{m}$ to $0.2 \mu \mathrm{m}$ and $0.45 \mu \mathrm{m}$ was observed at $10^{\circ} \mathrm{C}$. In summary, the operating temperature of $10^{\circ} \mathrm{C}$ is feasible for the fractionation of $\mathrm{IgG}$ and casein using ceramic membranes. Even though the low temperature will extend the filtration time, respectively, in the required filtration area, it could be necessary to use a lower temperature than $50{ }^{\circ} \mathrm{C}$ over extended filtration times since bovine antibodies are known to be heat sensitive [8]. 

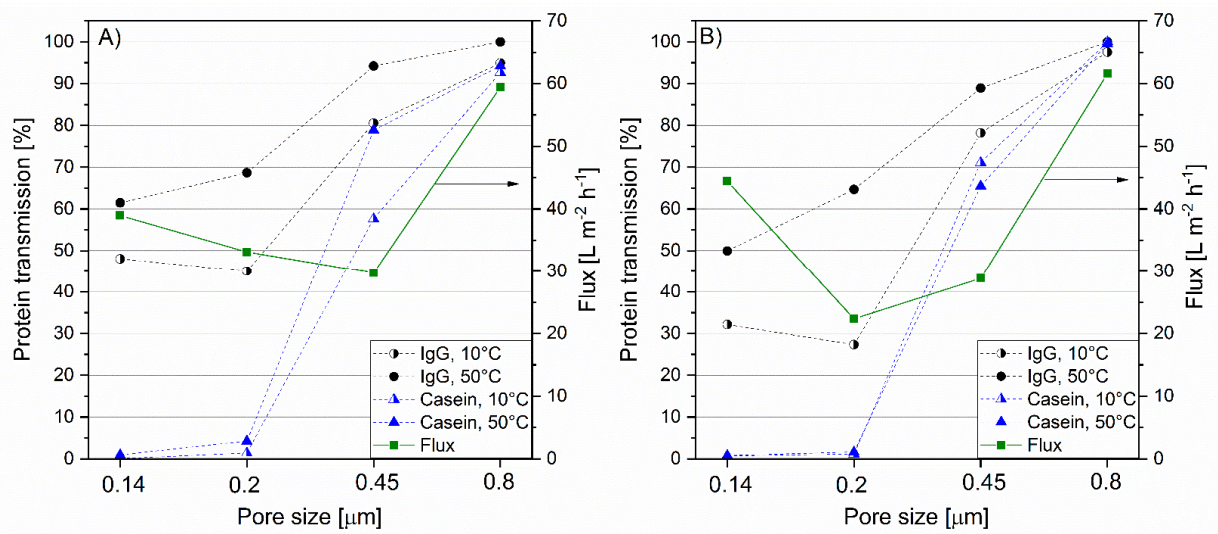

Figure 6. IgG and casein transmission plus flux as a function at $10{ }^{\circ} \mathrm{C}$ and $50{ }^{\circ} \mathrm{C}$ at $\Delta \mathrm{p}_{\mathrm{TM}}=1$ bar (A) and $\Delta \mathrm{p}_{\mathrm{TM}}=2$ bar $(\mathbf{B})$ as a function of pore size at steady state conditions using gradient membranes. Arrows indicate the belonging of the flux curve to the right $y$-axis. For equivalent $\beta$ - $L g$ and time-dependent data, see the Supplementary Information.

\section{Conclusions}

The aim of this work was to determine whether it is possible to use ceramic microfiltration for the fractionation of casein micelles and bovine IgG and, if so, which pore size and operating conditions should be used. Membranes with pore sizes of $0.2 \mu \mathrm{m}, 0.45 \mu \mathrm{m}$, and $0.8 \mu \mathrm{m}$, irrespective of membrane type (standard or gradient) and operating parameters such as transmembrane pressure (1 bar or 2 bar) and temperature $\left(10{ }^{\circ} \mathrm{C}\right.$ or $\left.50{ }^{\circ} \mathrm{C}\right)$, were inapplicable for the fractionation of IgG and casein due to casein transmission. In contrast, it was found that ceramic gradient membranes with a pore sizes of $0.14 \mu \mathrm{m}$ featured IgG-transmission rates between $45 \%$ to $62 \%$ depending on the process conditions while reducing the casein fraction below $1 \%$ in the permeates. The transmission of IgG taken as a model protein for immunological active proteins in whey was observed to be similar than that of the much smaller globular major whey protein fractions $\beta$-Lg and $\alpha$-La while the intermediate-sized and ellipsoidal BSA showed a lower transmission. Transferring the observed results to a continuous process offers new possibilities for production of immunoglobulin enriched supplements using industrial filtration equipment on a large scale.

Supplementary Materials: The following are available online at http:/ /www.mdpi.com/2304-8158/7/7/101/s1.

Author Contributions: H.J.H., J.T.S. and U.K. conceived and designed the experiments. H.J.H. performed the experiments and analyzed the data. H.J.H. wrote the paper. J.T.S. and U.K revised the paper. All authors read and approved the final manuscript.

Acknowledgments: The costs to publish in open access were funded by foods. We gratefully acknowledge M.S., Y.R., L.E.P., G.U., C.G., I.H. and H.W. for technical and analytical support.

Conflicts of Interest: The authors declare no conflict of interest.

\section{References}

1. Korhonen, H.; Marnila, P.; Gill, H.S. Bovine milk antibodies for health. Br. J. Nutr. 2000, 84, 135-146. [CrossRef]

2. Steele, J.; Sponseller, J.; Schmidt, D.; Cohen, O.; Tzipori, S. Hyperimmune bovine colostrum for treatment of GI infections: A review and update on Clostridium difficile. Hum. Vanccines Immunother. 2013, 9, 1565-1568. [CrossRef] [PubMed]

3. Marnila, P.; Korhonen, H. Encyclopedia of Dairy Sciences, 2nd ed.; Fuquay, J.W., Ed.; Academic Press: San Diego, CA, USA, 2011; pp. 807-815.

4. Van Dissel, J.T.; de Groot, N.; Hensgens, C.M.; Numan, S.; Kuijper, E.J; Veldkamp, P.; van't Wout, J. Bovine antibody-enriched whey to aid in the prevention of a relapse of Clostridium difficile-associated diarrhoea: Preclinical and preliminary clinical data. J. Med. Microbiol. 2005, 54, 197-205. [CrossRef] [PubMed] 
5. Young, K.W.H.; Munro, I.C.; Taylor, S.L.; Veldkamp, P.; van Dissel, J.T. The safety of whey protein concentrate derived from the milk of cows immunized against Clostridium difficile. Regul. Toxicol. Pharmacol. 2007, 47, 317-326. [CrossRef] [PubMed]

6. Numan, S.C.; Veldkamp, P.; Kuijper, E.J.; van den Berg, R.J.; van Dissel, J.T. Clostridium difficile-associated diarrhoea: Bovine anti-Clostridium difficile whey protein to help aid the prevention of relapses. Gut 2007, 56, 888-889. [CrossRef] [PubMed]

7. Chen, C.; Chang, H. Effect of Thermal Protectants on the Stability of Bovine Milk Immunoglobulin G. J. Agric. Food Chem. 1998, 46, 3570-3576. [CrossRef]

8. Mainer, G.; Sanchez, L.; Ena, J.M.; Calvo, M. Kinetic and Thermodynamic Parameters for Heat Denaturation of Bovine Milk IgG, IgA and IgM. J. Food Sci. 1997, 62, 1034-1038. [CrossRef]

9. Saboyainsta, L.V.; Maubois, J.-L. Current developments of microfiltration technology in the dairy industry. Le Lait 2000, 80, 541-553. [CrossRef]

10. Gosch, T.; Apprich, S.; Kneifel, W.; Novalin, S. Improved isolation of bioactive components of bovine colostrum using cross-flow microfiltration. Int. J. Dairy Technol. 2013, 66, 175-181. [CrossRef]

11. Le Berre, O.; Daufin, G. Skimmilk crossflow microfiltration performance versus permeation flux to wall shear stress ratio. J. Membr. Sci. 1996, 117, 261-270. [CrossRef]

12. Kulozik, U.; Kersten, M. New Ways for the Fractionation of Dairy and Minor Constituents Using UTP-Membrane Technology. Bull. Int. Dairy Fed. 2002, 374, 37-42.

13. Jimenez-Lopez, A.J.E.; Leconte, N.; Dehainault, O.; Geneste, C.; Fromont, L.; Gésan-Guiziou, G. Role of milk constituents on critical conditions and deposit structure in skimmilk microfiltration $(0.1 \mu \mathrm{m})$. Sep. Purif. Technol. 2008, 61, 33-43. [CrossRef]

14. Jimenez-Lopez, A.J.E.; Leconte, N.; Garnier-Lambrouin, F.; Bouchoux, A.; Rousseau, F.; Gésan-Guiziou, G. Ionic strength dependence of skimmed milk microfiltration: Relations between filtration performance, deposit layer characteristics and colloidal properties of casein micelles. J. Membr. Sci. 2011, 369, 404-413. [CrossRef]

15. Piry, A.; Kühnl, W.; Tolkach, A.; Ripperger, S.; Kulozik, U. Length dependency of flux and protein permeation in crossflow microfiltration of skimmed milk. J. Membr. Sci. 2008, 325, 887-894. [CrossRef]

16. Piry, A.; Heino, A.; Kühnl, W.; Grein, T.; Ripperger, S.; Kulozik, U. Effect of membrane length, membrane resistance, and filtration conditions on the fractionation of milk proteins by microfiltration. J. Dairy Sci. 2012, 95, 1590-1602. [CrossRef] [PubMed]

17. Kühnl, W.; Piry, A.; Kaufmann, V.; Grein, T.; Ripperger, S.; Kulozik, U. Impact of colloidal interactions on the flux in cross-flow microfiltration of milk at different $\mathrm{pH}$ values: A surface energy approach. J. Membr. Sci. 2010, 352, 107-115. [CrossRef]

18. Steinhauer, T.; Kühnl, W.; Kulozik, U. Impact of protein interactions and transmembrane pressure on physical properties of filter cakes formed during filtrations of skim milk. Procedia Food Sci. 2011, 1, 886-892. [CrossRef]

19. Steinhauer, T.; Lonfat, J.; Hager, I.; Gebhardt, R.; Kulozik, U. Effect of pH, transmembrane pressure and whey proteins on the properties of casein micelle deposit layers. J. Membr. Sci. 2015, 493, 452-459. [CrossRef]

20. Adams, M.C.; Barbano, D.M. Serum protein removal from skim milk with a 3 -stage, $3 \times$ ceramic Isoflux membrane process at $50^{\circ} \mathrm{C}$. J. Dairy Sci. 2013, 96, 2020-2034. [CrossRef] [PubMed]

21. Jørgensen, C.E.; Abrahamsen, R.K.; Rukke, E.-O.; Johansen, A.-G.; Schüller, R.B.; Skeie, S.B. Optimization of protein fractionation by skim milk microfiltration: Choice of ceramic membrane pore size and filtration temperature. J. Dairy Sci. 2016, 99, 6164-6179. [CrossRef] [PubMed]

22. Piot, M.; Fauquant, J.; Madec, M.N.; Maubois, J.L. Preparation of serocolostrum by membrane microfiltration. Le Lait 2004, 84, 333-341. [CrossRef]

23. Le Berre, O.; Daufin, G. Microfiltration $(0 \cdot 1 \mu \mathrm{m})$ of milk: Effect of protein size and charge. J. Dairy Res. 1998, 65, 443-455. [CrossRef]

24. Kessler, H.G.; Beyer, H.J. Thermal denaturation of whey proteins and its effect in dairy technology. Int. J. Biol. Macromol. 1991, 13, 165-173. [CrossRef]

25. Toro-Sierra, J.; Tolkach, A.; Kulozik, U. Fractionation of a-Lactalbumin and B-Lactoglobulin from Whey Protein Isolate Using Selective Thermal Aggregation, an Optimized Membrane Separation Procedure and Resolubilization Techniques at Pilot Plant Scale. Food Bioprocess Technol. 2013, 6, 1032-1043. [CrossRef] 
26. Bonfatti, V.; Grigoletto, L.; Cecchinato, A.; Gallo, L.; Carnier, P. Validation of a new reversed-phase high-performance liquid chromatography method for separation and quantification of bovine milk protein genetic variants. J. Chromatogr. A 2008, 1195, 101-106. [CrossRef] [PubMed]

27. Bonizzi, I.; Buffoni, J.N.; Feligini, M. Quantification of bovine casein fractions by direct chromatographic analysis of milk. Approaching the application to a real production context. J. Chromatogr. A 2009, 1216, 165-168. [CrossRef] [PubMed]

28. Schroeder, H.W.; Cavacini, L. Structure and function of immunoglobulins. J. Allergy Clin. Immunol. 2010, 125, S41-S52. [CrossRef] [PubMed]

29. Gapper, L.W.; Copestake, D.E.J.; Otter, D.E.; Indyk, H.E. Analysis of bovine immunoglobulin G in milk, colostrum and dietary supplements: A review. Anal. Bioanal. Chem. 2007, 389, 93-109. [CrossRef] [PubMed]

30. Pettersen, E.F.; Goddard, T.D.; Huang, C.C.; Couch, G.S.; Greenblatt, D.M.; Meng, E.C.; Ferrin, T.E. UCSF Chimera-A visualization system for exploratory research and analysis. J. Comput. Chem. 2004, 25, 1605-1612. [CrossRef] [PubMed]

31. Saphire, E.O.; Parren, P.W.; Pantophlet, R.; Zwick, M.B.; Morris, G.M.; Rudd, P.M.; Dwek, R.A.; Stanfield, R.L.; Burton, D.R.; Wilson, I.A. Crystal structure of a neutralizing human IGG against HIV-1: A template for vaccine design. Science 2001, 293, 1155-1159. [CrossRef] [PubMed]

32. Piry, A. Untersuchung zur Längenanhängigkeit der Filtrationsleistung bei der Fraktionierung von Milchproteinen Mittels Mikrofiltration. Ph.D. Thesis, Technische Universität München, München, Germany, 2011.

33. Saxena, A.; Tripathi, B.P.; Kumar, M.; Shahi, V.K. Membrane-based techniques for the separation and purification of proteins: An overview. Adv. Colloid Interf. Sci. 2009, 145, 1-22. [CrossRef] [PubMed]

34. Brans, G.; Schroën, C.G.P.H.; van der Sman, R.G.M.; Boom, R.M. Membrane fractionation of milk: State of the art and challenges. J. Membr. Sci. 2004, 243, 263-272. [CrossRef]

35. Skrzypek, M.; Burger, M. Isoflux ${ }^{\circledR}$ ceramic membranes_Practical experiences in dairy industry. Conf. Fouling Clin. Flux Theor. Appl. 2010, 250, 1095-1100. [CrossRef]

36. Kulozik, U.; Kersten, M. Fraktionieren von Proteinen mittels Mikrofiltration. CIT 2001, 73, $1622-1625$. [CrossRef]

37. Samuelsson, G.; Dejmek, P.; Trägårdh, G.; Paulsson, M. Minimizing whey protein retention in cross-flow microfiltration of skim milk. Int. Dairy J. 1997, 7, 237-242. [CrossRef]

38. Espina, V.S.; Jaffrin, M.Y.; Ding, L.H. Comparison of rotating ceramic membranes and polymeric membranes in fractionation of milk proteins by microfiltration. Desalination 2009, 245, 714-722. [CrossRef]

39. Farrell, H.M.; Jimenez-Flores, R.; Bleck, G.T.; Brown, E.M.; Butler, J.E.; Creamer, L.K.; Hicks, C.L.; Hollar, C.M.; Ng-Kwai-Hang, K.F.; Swaisgood, H.E. Nomenclature of the Proteins of Cows' Milk-Sixth Revision. J. Dairy Sci. 2004, 87, 1641-1674. [CrossRef]

40. Coppola, L.E.; Molitor, M.S.; Rankin, S.A.; Lucey, J.A. Comparison of milk-derived whey protein concentrates containing various levels of casein. Int. J. Dairy Technol. 2014, 67, 467-473. [CrossRef]

41. Hurt, E.E.; Adams, M.C.; Barbano, D.M. Microfiltration of skim milk and modified skim milk using a 0.1- $\mu \mathrm{m}$ ceramic uniform transmembrane pressure system at temperatures of 50, 55, 60, and $65^{\circ}$ C. J. Dairy Sci. 2015, 98, 765-780. [CrossRef] [PubMed]

42. Dalgleish, D.G.; Corredig, M. The Structure of the Casein Micelle of Milk and Its Changes during Processing. Annu. Rev. Food Sci. Technol. 2012, 3, 449-467. [CrossRef] [PubMed]

43. Huppertz, T.; Hennebel, J.-B.; Considine, T.; Shakeel-Ur-Rehman; Kelly, A.L.; Fox, P.F. A method for the large-scale isolation of $\beta$-casein. Food Chem. 2006, 99, 45-50. [CrossRef]

44. Kessler, H.G. Lebensmittel-und Bioverfahrenstechnik. Molkereitechnologie; Technische Universität München-Weihnstephan: München, Germany, 1996.

45. Kersten, M.; Kulozik, U. Proteinfraktionierung mittels Membrantrennverfahren; VDI-Verlag: Munich, Germany, 2000.

(C) 2018 by the authors. Licensee MDPI, Basel, Switzerland. This article is an open access article distributed under the terms and conditions of the Creative Commons Attribution (CC BY) license (http://creativecommons.org/licenses/by/4.0/). 